\title{
PUBLICATIONS OF THE DE NOBILI RESEARCH LIBRARY
}

1. George Chemparathy, An Indian Rational Theology. Introduction to Udayana's Nyāyakusumāñjali. Vienna 1972. 202 p. (out of print)

2. Gerhard Oberhammer (ed.), Offenbarung, geistige Realität des Menschen. Arbeitsdokumentation eines Symposiums zum Offenbarungsbegriff in Indien. Wien 1974. 237p. (€ 23,26)

3. Vāsudevāśrama, Yatidharmaprakāśa. A Treatise on World Renunciation, critically edited with introduction, annotated translation and appendices by Patrick Olivelle. Part I: Text. Vienna 1976. 142p. (€ 23,26)

4. Vāsudevāśrama, Yatidharmaprakāśa. A Treatise on World Renunciation, critically edited with introduction, annotated translation and appendices by Patrick Olivelle. Part II: Translation. Vienna 1977. 231p. (€ 23,26)

5. Gerhard Oberhammer (ed.), Transzendenzerfahrung, Vollzugshorizont des Heils. Das Problem in indischer und christlicher Tradition. Arbeitsdokumentation eines Symposiums. Wien 1978. 253p. (€ 23,26)

6. Tilmann Vetter, Studien zur Lehre und Entwicklung Śankaras. Wien 1979. 154p. $(€ 23,26)$

7. Francis X. D'SA, Śabdaprāmānyam in Śabara und Kumārila. Towards a Study of the Mīmāṃsā Experience of Language. Vienna 1980. 218p. (€ 23,26)

8. Richard F. Young, Resistant Hinduism. Sanskrit Sources on Anti-Christian Apologetics in Early Nineteenth-Century India. Vienna 1981. 200p. (€ 23,26)

9. Gerhard Oberhammer (ed.), Epiphanie des Heils. Zur Heilsgegenwart in indischer und christlicher Religion. Arbeitsdokumentation eines Symposiums. Wien 1982. 256p. (€ 23,26)

10. Gudrun Bühnemann, Budha-Kauśika's Rāmarakṣāstotra. A Contribution to the Study of Sanskrit Devotional Poetry. Vienna 1983. 125p. (€ 20,35)

11. Anand Amaladass, Philosophical Implications of Dhvani. Experience of Symbol Language in Indian Aesthetics. Vienna 1984. 240p. (€ 23,26)

12. Paul Hacker $\dagger$, Grundlagen indischer Dichtung und indischen Denkens. Aus dem Nachlaß herausgegeben von KLaus RÜPING. Wien 1985. 148p. (€ 21,80)

13. Patrick Olivelde, Renunciation in Hinduism. A Medieval Debate. Vol. 1: The Debate and the Advaita Argument. Vienna 1986. 156p. (€ 26,16)

14. Patrick Olivelle, Renunciation in Hinduism. A Medieval Debate. Vol. 2: The Viśișțādvaita Argument. Vienna 1987. 193p. (€ 26,16)

15. Gudrun Bühnemann, Pūjā. A Study in Smārta Ritual. Vienna 1988. 253p. $(€ 32,70)$

16. James W. Laine, Visions of God. Narratives of Theophany in the Mahābhārata. Vienna 1989. 304p. $(€ 26,16)$ 
17. Francis X. Clooney, S.J., Thinking Ritually. Rediscovering the Pūrva Mīmāmsāā Experience of Jaimini. Vienna 1990. 293p. (€ 26,16)

18. Christopher Z. Minkowski, Priesthood in Ancient India. A Study of the Maitrāvaruṇa Priest. Vienna 1991. 272p. (€ 26,16)

19. Yoshitsugu Sawai, The Faith of Ascetics and Lay Smārtas. A Study of the Śankaran Tradition of Śrn்geri. Vienna 1992. 199p. (€ 26,16)

20. F.X. D'SA - R. Mesquita (eds.), Hermeneutics of Encounter. Essays in Honour of Gerhard Oberhammer on the Occasion of his $65^{\text {th }}$ Birthday. Vienna 1994. $1+303 p .(€ 29,07)$

21. Max Ninom, Studies in Indian and Indo-Indonesian Tantrism. The Kuñjarakarṇadharmakathana and the Yogatantra. Vienna 1994. 222p. (€ 29,07)

22. R.F. Young - S. Jebanesan, The Bible Trembled. The Hindu-Christian Controversies of Nineteenth-Century Ceylon. Vienna 1995. 204p. (€ 29,07)

23. R.F. Young - G.P.V. Somaratna, Vain Debates. The Buddhist-Christian Controversies of Nineteenth-Century Ceylon. Vienna 1996. 236p. (€ 29,07)

24. R. Mesquita, Madhva und seine unbekannten literarischen Quellen. Einige Beobachtungen. Wien 1997. 151p. (€ 29,07)

25. Кіуотака Yoshimizu, Der 'Organismus' des urheberlosen Veda. Eine Studie der Niyoga-Lehre Prabhākaras mit ausgewählten Übersetzungen der Bṛhatī. Wien 1997. 430p. (€ 36,34)

26. Thomas Oberlies, Die Religion des Rgveda. Erster Teil - Das religiöse System des Rgveda. Wien 1998. 632p. (€ 67,59)

27. Thomas Oberlies, Die Religion des Rgveda. Zweiter Teil - Kompositionsanalyse der Soma-Hymnen des Rgveda. Wien 1999. 313p. (€ 29,07)

28. Roque Mesquita, Madhva: Viṣnutattvanirnaya. Annotierte Übersetzung mit Studie. Wien 2000. 562p. (€ 69,04)

29. Marcus Schmücker, Weder als seiend noch als nicht-seiend bestimmbar. Vimuktātmans Lehre von der "Realität" der Welt. Wien 2001. 187p. (€ 28,-)

30. Minoru Hara, Pāśupata Studies. Ed. by Jun Takashima. Vienna 2002. 320p. $(€ 45,-)$

31. Marzenna Czerniak-Droźdźowicz, Pañcarātra Scripture in the Process of Change. A Study of the Paramasaṃitā. Vienna 2003. 226p. (€ 35,-)

32. Gerhard Oberhammer: Ausgewählte Kleine Schriften. Hrsg. von Utz Podzeit [u.a.]. Ca. 750p. (in Vorbereitung zum Druck).

\section{OCCASIONAL PAPERS}

1. Gerhard Oberhammer - Hans Waldenfels, Überlieferungsstruktur und Offenbarung. Aufriß einer Reflexion des Phänomens im Hinduismus mit theologischen Anmerkungen. Wien 1980. 55p. (€ 5,81) 
2. Gerhard Oberhammer (ed.), Inklusivismus. Eine indische Denkform. Wien 1983. 113p. $(€ 10,17)$

3. Gerhard Oberhammer, Versuch einer transzendentalen Hermeneutik religiöser Traditionen. Wien 1987. 48p. (€ 7,27)

4. Gerhard Oberhammer, 'Begegnung' als Kategorie der Religionshermeneutik. Wien 1989. 60p. $(€ 7,27)$

5. Gerhard Oberhammer, Offenbarungsgeschichte als Text. Religionshermeneutische Bemerkungen zum Phänomen in hinduistischer Tradition. Wien 1994. 109p. $(€ 11,63)$

6. Gerhard Oberhammer, Transzendenzerfahrung als absolute Begegnung. Wien 2003. 55p. (€ 10,-)

Sole distributor:

Sammlung de Nobili

c/o Institute for South Asian, Tibetan and Buddhist Studies - Department of South Asian Studies,

University of Vienna,

Spitalgasse 2, Hof 4/2.1

A-1090 Vienna

Austria 
